\title{
THE FIRST RECEPTION OF CHINESE LITERATURE AND CULTURE IN ROMANIA
}

\author{
Li CAIYUE \\ Beijing Language and Culture University, Beijing, China, e-mail: licaiyue@yahoo.com
}

\begin{abstract}
Although the bilateral diplomatic relations between China and Romania have 65 years, the communication and cooperation in the fields of education, science and technology, culture and politics have a long history. And what's more there is a traditional friendship between the Romanian and Chinese people. When we talk about the first reception of Chinese literature and culture in Romania, we can't forget one important person-Nicolae Milescu Spatarul and his contribution. In this paper first I will talk about the brief introduction of the relationship between Romania and China, and then I will focus on Nicolae Milescu Spatarul and his famous books Jurnal de călătorie în China, Descrierea Chinei.Jurnal de calatorie in China.
\end{abstract}

KEY WORDS: communication; China; Romania; Nicolae Milescu Spatarul

\section{BRIEF INTRODUCTION OF THE RELATIONSHIP BETWEEN ROMANIA AND CHINA}

Since the beginning of the formation of human culture, different ethnic groups and different forms of culture already had communication. The main cultural communication parts are the Eastern culture in which China and India are the representatives and Western culture. The exclusion and blend, confrontation and dialogue between them produced influence which can't be underestimated.

China and Romania belong to Eastern and Western culture. Their historical origin, cultural background and literary tradition and National psychological structure are entirely different. Romania is far away from the politically, economically and culturally developed European countries. Even in European countries, its national language is like a Latin isolated island among the Slavic nations and languages and it's difficult to enter the international communication stage. Additionally, the Western culture pushed aside Romanian culture for a long time, so in Romanian history, no matter the acceptance of Chinese culture or dissemination of its own culture, Romanian relatively lagged behind. However, the cultural communication between China and Romania is an exception, it is not only kept a good continuity, but also had a rich content and diverse forms, especially the literature communication is one of the most important and steady field. This paper will show you the first reception of Chinese literature and culture in Romania

\section{NICOLAE SPATARUL MILESCU AND THE BEGINNING OF CHINESE AND ROMANIAN LITERATURE RELATIONSHIP}

In the relationship between Romania and China, Nicolae Spatarul Milescu has a prominent contribution. In the late 17th century, as a Romanian traveler, he wrote a best known book Travel in China based on his own experience, which brought him into a great diplomat. He was one of the earlier European messengers who introduced China to the West. He is considered to be a pioneer of the relationship between Romania and China, Moldova and China; he also played an important role between the relationship of Russia and China.

Nicolae Milescu Spatarul $(1636-1708)$ was born in Vaslui, a city in Eastern Romania. In 1675, he was named ambassador of the Russian Empire to China, Beijing. During that China is feudal Qing dynasty, he were marshaled into the presence of the Kangxi Emperor. After 1678, he left China, and wrote famous book Jurnal de cãlãtorie în China, Descrierea Chinei. He opened a new passage from Moscow to Beijing through Siberia. And he was called the Moldavian Marco Polo.

In 17th century, Russia's politics and economy entered into a turbulent period. The external relations were restricted more and more serious by the Baltic and Black Sea military groups. The commercial trade between the port city Arkhangelsk and western European countries can not satisfied the demand for the development of domestic manufacturing, the Central Asia and the Caucasus's market was controlled by Persian and Turkish businessmen. In order to develop its own economy and social culture, Russian needs to find a new way urgently. In this case, Russia began to expanse from Europe to the northeast Asia, from Yenisei River, Lena River to east, until the north part of China. 
From $1630 \mathrm{~s}$ to $1680 \mathrm{~s}$ is the initial moment of the communication between China and Russia. During this period, China and Russia had different kinds of diplomatic struggle which include messengers sending, delivery of credentials, negotiation and war. In the year of 1689, Russia and China signed first treaty-The Treaty of Nerchinsk. Milescu left for China with a group of 150 persons on 3rd March 1675. On 25th May, the diplomatic corps arrived in Beijing. According to the emperor Kangxi daily life record, emperor Kangxi met Milescu Spatarul on $25^{\text {th }}$ June. On $22^{\text {nd }}$ July, he was bestowed dinner and wine. On $1^{\text {st }}$ September 1676, Milescu Spatarul and his diplomatic corps went back to Russia.

The main achievement of Milescu Spatarul's travelling in China reflect on his works Jurnal de calatorie in China, Descrierea Chineisi a marelui fluviu Amur.

At that time, no matter Russia or the whole Europe, China is a rather obscure and attractive place which is full of magic. Milescu Spatarul's works are very important for many European writers.

Nicolae Milescu Spataru is not only a pioneer in the Russian and Chinese relations, he is also a forerunner between Romanian and Chinese literature. The main factors are he is a Romanian or Moldovan identity; his works has special literary value and status. His works also has a potential influence for the Chinese literature works.

Travel notes - Road to China (Jurnal de calatorie in China) include two parts:

1. Calatorie de la Tobolsk, Capitala Siberiei, Pana la Hotarele Chinei, Intru Aceasta si despre Pamantul Siberiei si despre riurile ei.

2. Documentul de stat al solieilui Nicolae Spataru in China (1675-1676).

In this travel note, the author noted the passage from Siberia to China, described the mountains and landscapes, climate and plants, traffic fortress, natural resources, and customs along the road. In the travel note there are many descriptions about rivers and the local people.

Marele si celebrul fluviu Obi, care este cunoscut de toti geografii vechi si noi, fiind ca ei il pun ca hotar de despartire intre Asia si Europa si nu este un alt fluviu in lume, afara de Amur... Cele intaii izvoare ale lui Obi vin din balta tobolica numita Telezka, pe care buharii o numesc si Kaltin; acolo locuiesc multi necredinciosi saghianti, munduti, manti, tauteleuti, iaumderti, eui, karagaiti, care nu dau dari marelui domn' iar pamintul pe acolo este productiv pentru semanaturi si sunt campii si paduri.-(Jurnal de calatorie in China-1962 Editie ingrijita, traducere, note si prefata de Corneliu Barbulescu - page 45-46)
In Documentul de stat al soliei lui Nicolae Spataru in China (1675-1676), the author narrated what he saw and met after he arrived in China.

Compare with Travel notes - Road to China, the description of China (Descrierea Chinei) is much more interesting. It contains 58 chapters, among them, the first 20 chapters introduced the great "Imperial China" briefly, which include history, territory, the land route and sea route to China, provinces and population, religion, race characteristic, science and culture, wedding customs, food, construction feature, traffic, Great Wall and so on. From Chapter 21 to chapter 58, the author introduced the 15 provinces at that time, and the important cities. The last two chapters are about Korea and Japan.

\section{CONCLUSION}

Since Nicolae Spatarul Milescu visited China and brought Chinese culture into Romanian people's sight, the Chinese culture and literature were continuously introduced to Romania. Romanian scholars and common people showed great interests to this mysterious Asian country. The famous Romanian scholars like Titu Liviu Maiorescu, Ioan Slacivi and Mihai Eminescu were attracted and influenced by the Eastern and culture. Different kinds of newspapers and periodicals published articles about Chinese literature successively. Nowadays, Romanian people can learn Chinese culture through many ways. For example, three universities in Romania established Chinese major; they are Bucuresti University, Lucian Blaga University, Babes-Bolya University. Besides this, there are four Confucius institutes, two Confucius classes and more than 20 Chinese teaching centers in Romania. Romanian students not only can learn Chinese language, they also can learn the culture and Chinese literature in Romanian in Romania.

\section{Bibliography}

1. Nicolae Milescu- Spataru, Jurnal de calatorie in China, Editieingrijita, traduce, note siprefata de Corneliu Barbulescu, 1962.

2. Galinescu, George, Istoria literaturii romane de la originipana in present, editia a II-a, adaugitasiingrijita de Al. Piru, Bucuresti, 1982.

3. Ding Chao, $O$ istorie a relatiilor literare chino-române, People's Literature Publishing House, Beijing, 2008.

4. Feng Zhi chen, Literatura Romana, Foreign Language Teaching and Research Press, Beijing, 2001

5. Song Binghui, Method and practice-the research on Chinese and foreign Literary Relationship, Fudan University Press, 2004.

6. AnTianpu, The history of Chinese culture in western countries, Commercial Press, 2000 